\title{
Estradiol suppresses phosphorylation of ER $\alpha$ serine 167 through upregulation of PP2A in breast cancer cells
}

\author{
TAKANORI HAYASHI ${ }^{1}$, MASAHIRO HIKICHI $^{2}$, JUN YUKITAKE ${ }^{3}$, \\ NOBUHIRO HARADA ${ }^{1}$ and TOSHIAKI UTSUMI ${ }^{2}$
}

\begin{abstract}
Departments of ${ }^{1}$ Biochemistry and ${ }^{2}$ Breast Surgery, School of Medicine; ${ }^{3}$ Department of Clinical Immunology, School of Health Sciences, Fujita Health University, Toyoake, Aichi 470-1192, Japan
\end{abstract}

Received February 13, 2017; Accepted September 7, 2017

DOI: 10.3892/ol.2017.7216

\begin{abstract}
Aromatase inhibitors (AIs) are effective endocrine therapeutics for postmenopausal women with estrogen receptor (ER) $\alpha$-positive breast cancer. However, the efficacy of the treatment is often limited by the onset of AI resistance, owing to the phosphorylation of ER $\alpha$ serine 167 (Ser167). Previous studies have indicated that hyperactivation of the phosphoinositide-3 kinase/RAC serine/threonine-protein kinase signaling pathway occurs in AI-resistant breast cancer models, which coincides with elevated levels of ER $\alpha$ phosphorylation at Ser167. The tumor suppressor serine/threonine-protein phosphatase $2 \mathrm{~A}$ (PP2A) regulates the phosphatidylinositol 3-kinase/RAC serine/threonine-protein kinase signaling pathway. A previous study indicated that PP2A inhibition decreased ER $\alpha$ Ser167 phosphorylation and estradiol $\left(\mathrm{E}_{2}\right)$-independent cell growth. The present study investigated the potential relevance of PP2A in $\mathrm{E}_{2}$ deprivation-resistant MCF-7 cells. $\mathrm{E}_{2}$ depletion reduced the susceptibility of MCF-7 cells to inhibitors of mechanistic target of rapamycin (mTOR) and significantly increased ER $\alpha$ Ser167 phosphorylation and decreased expression of PP2A. Conversely, long-term $\mathrm{E}_{2}$-deprived (LTED) MCF-7 cells, a model of AI-resistant breast cancer, exhibited decreased ER $\alpha$ Ser167 phosphorylation and further upregulation of PP2A in $\mathrm{E}_{2}$-containing medium. The PP2A activator forskolin (FSK) significantly inhibited LTED cell proliferation by increasing the effect of everolimus (Eve), an mTOR inhibitor. In summary, the present study provides further evidence that PP2A represents a therapeutic target for AI-resistant breast cancer.
\end{abstract}

Correspondence to: Dr Takanori Hayashi, Department of Biochemistry, School of Medicine, Fujita Health University, 1-98 Dengakugakubo, Kutsukakechou, Toyoake, Aichi 470-1192, Japan

E-mail: thayshi@fujita-hu.ac.jp

Key words: breast cancer, aromatase inhibitor, estrogen receptor, protein phosphatase $2 \mathrm{~A}$

\section{Introduction}

Estradiol $\left(\mathrm{E}_{2}\right)$ has an essential role in the development and progression of estrogen receptor (ER)-positive breast cancer $(1,2)$. Therefore, the use of aromatase inhibitors (AIs), including letrozole, anastrozole and exemestane, as adjuvants is regarded as a standard approach in postmenopausal women with ER-positive breast cancer (3-5). However, certain patients with breast cancer develop resistance to AIs following long-term treatment (6). Previous studies have revealed crosstalk between the activation of the insulin-like growth factor-1 (IGF-I) signaling pathway and ER $\alpha$ in long-term AI-treated breast cancer cells $(7,8)$. One mechanism of AI resistance is aberrant signaling through the phosphatidylinositol 3-kinase (PI3K)/RAC serine/threonine-protein kinase (Akt)/mechanistic target of rapamycin (mTOR) signaling pathway $(8,9)$ (Fig. 1A).

Accordingly, the interruption of $\mathrm{PI} 3 \mathrm{~K} / \mathrm{Akt} / \mathrm{mTOR}$ signaling has been demonstrated in preclinical $\mathrm{E}_{2}$-deprivation resistance models, in which an mTOR inhibitor in combination with exemestane led to abrogation of proliferation, induction of apoptosis and enhanced tumor regression (10). A substrate of mTOR complex 1, S6 kinase 1 (S6K), phosphorylates activation function domain 1 of $E R \alpha$, which is responsible for ligand-independent receptor activation $(7,8,11)$. IGF-1-dependent activation of ER $\alpha$ was proposed as the reason for AI resistance, and the role of $\mathrm{S} 6 \mathrm{~K}$ was elucidated in previous studies $(7,12)$. Abnormal activation of ER $\alpha$ is dependent on the phosphorylation of Ser104, Ser106, Ser118 and Ser167, located in the amino terminal A/B domain of ER $\alpha(13,14)$. The phosphorylation level of proteins is determined by the activity and balance of protein kinases, and phosphatases. Using the phosphatase inhibitor okadaic acid (OA) $(15,16)$, a previous study demonstrated that serine/threonine-protein phosphatase $2 \mathrm{~A}$ (PP2A) has an important role in the regulation of ER $\alpha$ Ser167 phosphorylation and in the proliferation of MCF-7 cells (17).

PP2A is a key tumor suppressor that regulates signaling pathways relevant to a number of types of human cancer $(18,19)$. PP2A is a ubiquitously expressed member of a phosphoserineand phosphothreonine-specific protein phosphatase family involved in the regulation of cell proliferation, cell differentiation, RNA transcription, DNA repair and apoptosis (20-22). As inhibition of its activity and loss of certain functional subunits are characteristics of neoplastic transformation, PP2A is widely 
designated as a tumor suppressor (23). Forskolin (FSK) lacks adenylate cyclase-activating function but retains the ability to activate PP2A, which is necessary for growth inhibition and induction of apoptosis induction in leukemic cells (23).

In the present study, $\mathrm{E}_{2}$ depletion decreased PP2A expression and reduced the susceptibility of MCF-7 cells to mTOR inhibitors. Furthermore, activation of PP2A by FSK enhanced the effect of everolimus (Eve) and strongly inhibited long-term $\mathrm{E}_{2}$-deprived (LTED) cell proliferation.

\section{Materials and methods}

Cell culture. Human ER-positive breast cancer MCF-7 cells (American Type Culture Collection., Manassas, VA, USA) were maintained in RPMI 1640 medium (Gibco; Thermo Fisher Scientific, Inc., Waltham, MA, USA) supplemented with $10 \%$ fetal bovine serum (FBS; Nichirei Biosciences, Inc., Tokyo, Japan) and $1 \%$ penicillin/streptomycin at $37^{\circ} \mathrm{C}$ in a $5 \% \mathrm{CO}_{2}$-humidified atmosphere incubator. Cells treated with 17 $\beta$-estradiol ( $\mathrm{E}_{2}$ ) (Sigma-Aldrich; Merck KGaA, Darmstadt, Germany), Phos STOP (Sigma-Aldrich; Merck KGaA), OA, calyculin A (CalA), rapamycin and Eve (Wako Pure Chemical Industries, Ltd., Osaka, Japan) in Dimethyl sulfoxide (DMSO; Wako Pure Chemical Industries, Ltd.) were cultured in phenol-red-free RPMI 1640 medium (Gibco; Thermo Fisher Scientific, Inc.) supplemented with $10 \%$ dextran-coated charcoal (DCC)-treated FBS (Nichirei Biosciences, Inc.) and $1 \%$ penicillin/streptomycin. MCF-7 cells cultured in phenol-red-free RPMI 1640 with $10 \%$ dextran-coated charcoal (DCC)-treated FBS and $10 \mathrm{nM} \mathrm{E}_{2}$ and then for 5 days without $\mathrm{E}_{2}$ (MCF-7 5d) and 6 months without $\mathrm{E}_{2}$ (LTED) were used in the experiment. LTED cells modeling AIs resistance were derived from a parental cell line by long-term culture in the presence of RPMI 1640 medium containing 10\% DCC-treated FBS, as described previously $(12,24,25)$. MCF-7 cells were cultured with E2 (10 nM), OA (100 nM), Cal A (1 nM), FK506 $(10 \mathrm{nM})$, or DMSO $(0.1 \%$, vehicle $)$ in phenol red-free RPMI 1640 medium supplemented with $10 \%$ dextran-coated charcoal fetal bovine serum for 5 days at $37^{\circ} \mathrm{C}$. The cell viability of cultured cells was determined using Cell Counting kit- 8 (Dojindo Molecular Technologies, Inc., Kumamoto, Japan) according to the manufacturer's protocol.

Western blot analysis. Whole-cell lysates were collected using lysis buffer [containing $62.5 \mathrm{mM}$ Tris $\mathrm{HCl} \mathrm{pH} \mathrm{6.8,}$ $5 \%$ 2-mercaptoethanol, $2 \%$ sodium dodecyl sulfate, $5 \%$ sucrose and $0.01 \%$ Bromophenol Blue (Wako Pure Chemical Industries, Ltd.)]. The protein content was subsequently determined using a RC DC ${ }^{\text {TM }}$ Protein Assay (Bio-Rad Laboratories, Inc., Hercules, CA, USA) with bovine serum albumin (Sigma-Aldrich; Merck KGaA) as the standard. For western blot analysis, solubilized proteins (5 $\mu \mathrm{g}$ of protein/lane) were separated by $10 \%$ SDS-PAGE and transferred to a polyvinylidene difluoride membrane (GE Healthcare, Chicago, IL, USA). Membranes were pre-incubated with ImmunoBlock (DS Pharma Biomedical Co., Ltd. Osaka, Japan) as a blocking regent at room temperature for $30 \mathrm{~min}$ and then incubated at $4^{\circ} \mathrm{C}$ overnight with antibodies at 1:1,000 dilution directed against Akt (cat. no. 9272S) and phosphorylated Akt Ser473 (cat. no. 4060S); Cell Signaling
Technology, Inc., Danvers, MA, USA, ER $\alpha$ (cat. no. sc-543), phosphorylated ER $\alpha$ Ser167 (cat. no. sc-101676), and ER $\alpha$ Ser118 (cat. no. sc-101675), or a b-actin antibody (cat. no. sc-47778; Santa Cruz Biotechnology, Inc., Santa Cruz, California, USA). The membrane was subsequently washed with TBS-Tween 20 (TBS-T) buffer $(20 \mathrm{mmol} / \mathrm{l}$ Tris- $\mathrm{HCl}$ (pH 7.5), $150 \mathrm{mmol} / \mathrm{l} \mathrm{NaCl}, 0.5 \%$ Tween-20) and incubated with a horseradish peroxidase-labeled secondary anti-rabbit (cat. no. 170-6515; Bio-Rad Laboratories, Inc., Hercules, CA, USA) or anti-mouse (cat. no. 330; MBL, Nagoya, Japan) IgG antibody for $1 \mathrm{~h}$ at room temperature. All antibodies were diluted in Can Get Signal Immunoreaction Enhancer solution (cat. no. NKB-101; Toyobo Life Science, Osaka, Japan). Once the membrane was washed with TBS-T buffer, immunoreactive bands were visualized using Immobilon Western Chemiluminescent HRP substrate (EMD Millipore, Billerica, MA, USA). The intensity of the chemiluminescence of specific bands was digitized using Cool Saver software version 1.2 (ATTO Corporation, Tokyo, Japan) and quantified.

Statistical analysis. All experimental data comparing more than two groups were analyzed by one-way analysis of variance followed by Fisher's protected least significant difference test. The software used for statistical analyses was SPSS v24 (IBM SPSS, Armonk, NY, USA). When differences were significant, subsequent analyses with post hoc t-tests with Bonferroni correction were performed. Other statistical comparisons were conducted by a two-tailed unpaired t-test. Data are presented as the mean \pm standard deviation. $\mathrm{P}<0.05$ was considered to indicate a statistically significant difference.

\section{Results}

$17 \beta$-estradiol depletion reduces the sensitivity to mTOR inhibitor treatment. MCF-7 cells have previously been used as a model for the study of the $\mathrm{E}_{2}$ response in vitro $(26,27)$. In vitro studies using $\mathrm{E}_{2}$ deprivation or chronic exposure to anti- $E_{2}$ have led to the isolation of hormone therapy-resistant variants of MCF-7 cells (12,24,25). LTED cells serve as a model of AIs-resistant breast cancer, and have been generated by several laboratories (25). When MCF-7 cells were cultured in a phenol-red-free RPMI 1640 with $10 \%$ dextran-coated charcoal (DCC)-treated FBS medium, ER $\alpha$ Ser167 phosphorylation decreased in a time-dependent manner (Fig. 1B). Next, MCF-7, MCF-7 5d and LTED cells were evaluated for sensitivity to mTOR inhibition. MCF-7, MCF7 5d and LTED were treated with various amounts of the mTOR inhibitor rapamycin (concentrations of $1,10,100$ or $1,000 \mathrm{nM}$ ) for $1 \mathrm{~h}$ at $37^{\circ} \mathrm{C}$, and the number of cells was measured with a Cell Counting kit 8 . Following treatment of the cells with $1 \mathrm{nM}$ rapamycin for $1 \mathrm{~h}$, phosphorylation of ER $\alpha$ Ser167 was determined by western blotting. The phosphorylation levels of ER $\alpha$ Ser167 were $~ 58$ and $20 \%$ higher in cells treated with in 1 , and $10 \mathrm{nM}$ rapamycin, respectively, compared with that in vehicle-treated MCF-7 control cells (Fig. 1C). By contrast, following culturing in the presence of $1,000 \mathrm{nM}$ rapamycin for $1 \mathrm{~h}$, the intracellular phosphorylation level of ER $\alpha$ Ser167 in LTED cells decreased to $\sim 50 \%$ of that observed in vehicle-treated control cells (Fig. 1C). 

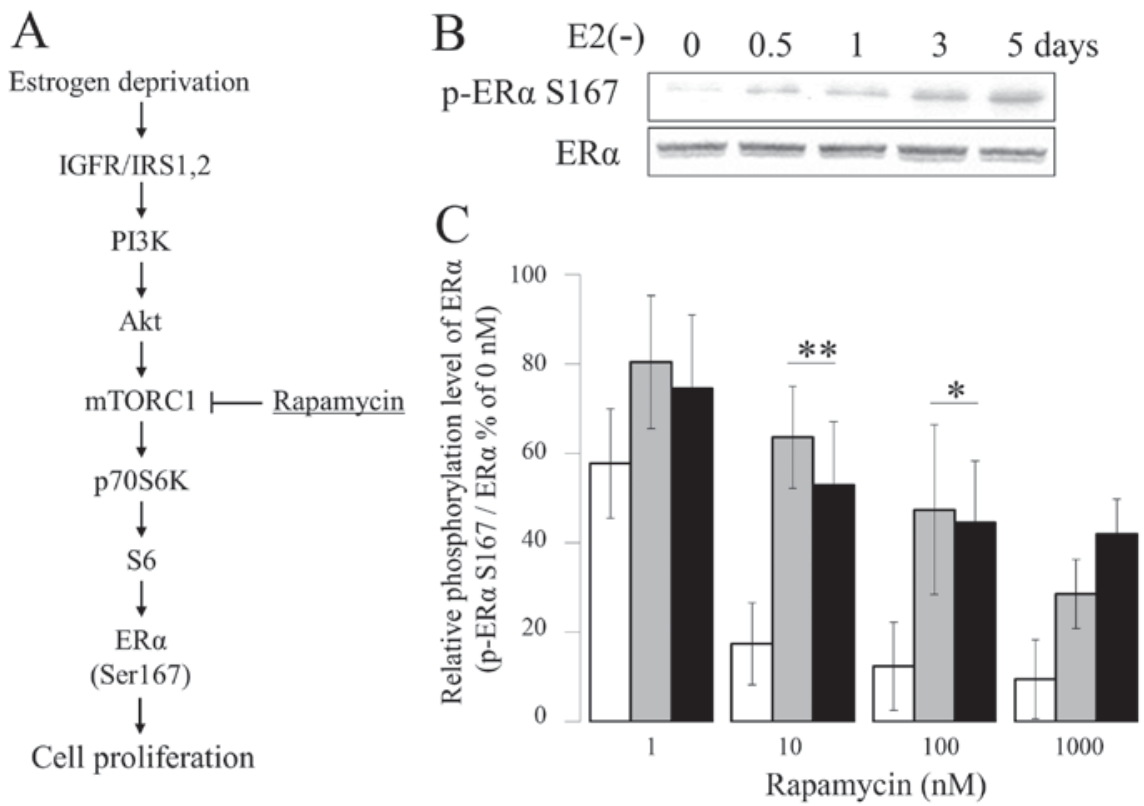

Figure 1. Suppressive effect of Eve on ER $\alpha$ Ser167 phosphorylation. (A) Schematic diagram of activated PI3K/Akt pathway in $\mathrm{E}_{2}$-deprivation breast cancer (B) Phosphorylation of ER $\alpha$ Ser167 in MCF-7 cells cultured in $\mathrm{E}_{2}$-deprived medium for 0-5 days. Calcium dependency of the degradation of microsomal aromatase in the presence of cytosol. MCF-7 (white bar), $\mathrm{E}_{2}$-deprived (5 days) MCF-7 (gray bar), and LTED (black bar) MCF-7 cells were incubated with the indicated concentration of rapamycin for $1 \mathrm{~h}(\mathrm{n}=4)$. "P<0.01. Eve, everolimus; ER $\alpha$, estrogen receptor- $\alpha$; $\mathrm{E}_{2}$, estradiol; LTED, long-term $\mathrm{E}_{2}$-deprived; PI3K, phosphoinositide 3-kinase; Akt, RAC serine/threonine-protein kinase; mTORC1, mechanistic target of rapamycin complex 1; IGFR, insulin-like growth factor receptor; IRS-1, insulin receptor substrate 1 .
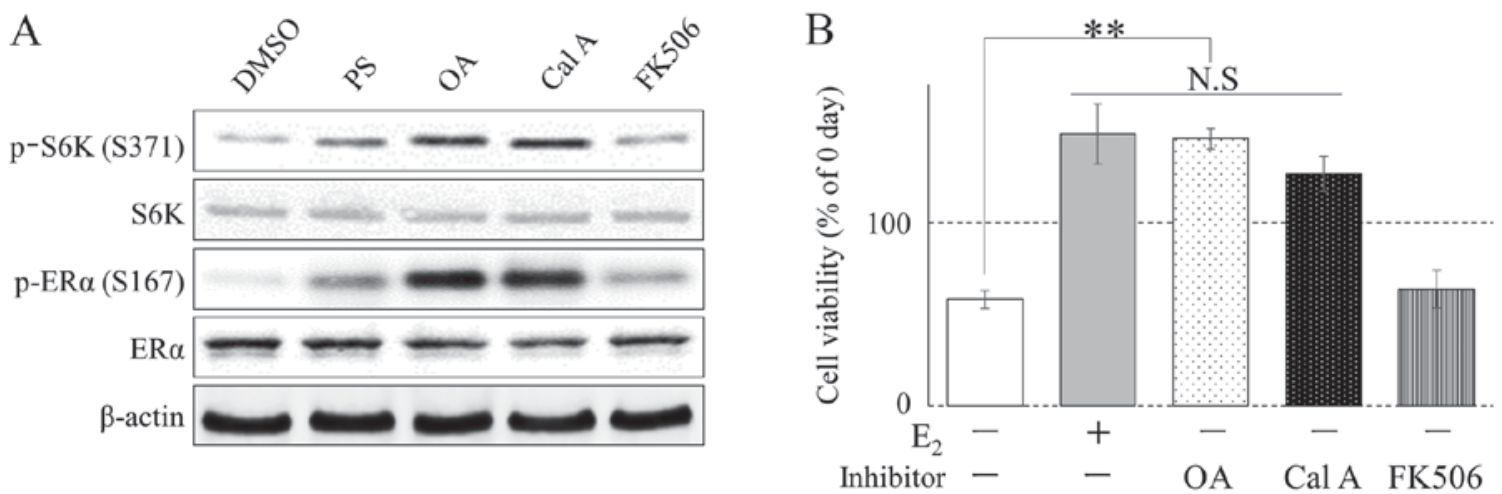

Figure 2. Alteration of the phosphorylation status of ER $\alpha$ and S6K in MCF-7 cells by phosphatase inhibitors. (A) MCF-7 cells were incubated with PS, OA (100 nM), Cal A (1 nM), FK506 (10 nM), or DMSO (0.1\%, vehicle) in $\mathrm{E}_{2}(10 \mathrm{nM})$ medium. Phosphorylation was determined by western blotting. (B) MCF-7 cells were cultured with $\mathrm{E}_{2}(10 \mathrm{nM})$, OA $(100 \mathrm{nM})$, Cal A $(1 \mathrm{nM})$, FK506 $(10 \mathrm{nM})$, or DMSO $(0.1 \%$, vehicle) in phenol red-free RPMI 1640 medium supplemented with $10 \%$ dextran-coated charcoal fetal bovine serum for 5 days $(n=4)$. Cell viability was analyzed using Cell Counting kit $8 .{ }^{*} \mathrm{P}<0.01,{ }^{* *} \mathrm{P}<0.001 . \mathrm{ER} \alpha$, estrogen receptor- $\alpha$; DMSO, dimethyl sulfoxide; S6K, S6 kinase; OA, okadaic acid; Cal A, calyculin A.

$P P 2 A$ inhibition leads to resistance to $E_{2}$ depletion via ERa Ser167 phosphorylation. Protein phosphorylation status is determined by the balance between phosphorylation and dephosphorylation. Previous studies have revealed that the mechanism of endocrine resistance involves aberrant signaling through the PI3K/Akt/mTOR signaling pathway $(7,12)$. However, the identity of the phosphatase involved in ER $\alpha$ phosphorylation remains unclear. Western blot analysis was conducted using several protein phosphatase inhibitors, which have been well characterized in phosphorylation studies (17). At $1 \mathrm{~h}$ after the addition of each inhibitor [Phos STOP (PS); protein phosphatase inhibitor cocktail, OA and Cal A; PP2A inhibitor, FK506; protein phosphatase type $2 \mathrm{~B}$ inhibitor], phosphorylation of ER $\alpha$
Ser167 was increased in the culture solution following PS, OA, FK506 and Cal A treatment (Fig. 2A). In addition, OA and $\mathrm{Cal} \mathrm{A}$ treatment increased the number of cells in the $\mathrm{E}_{2}$-free medium (Fig. 2B).

$E_{2}$ deprivation reduces PP $2 \mathrm{~A}$ levels in MCF-7 cells. $\mathrm{PP} 2 \mathrm{~A}$ is involved in endocrine therapy resistance (28). Therefore, MCF-7 cells cultured without steroids were examined after 1 or 5 days, which activated mTOR. Levels of phosphorylated ER $\alpha$ Ser167 were analyzed by western blotting. Phosphorylation of ER $\alpha$ Ser167 in LTED cells was induced by long-term $\mathrm{E}_{2}$ deprivation in MCF-7 parental cells. ER $\alpha$ Ser167 phosphorylation in MCF-7 cells cultured under $\mathrm{E}_{2}$ depletion for 1 day with LTED was increased 6-fold, 
A
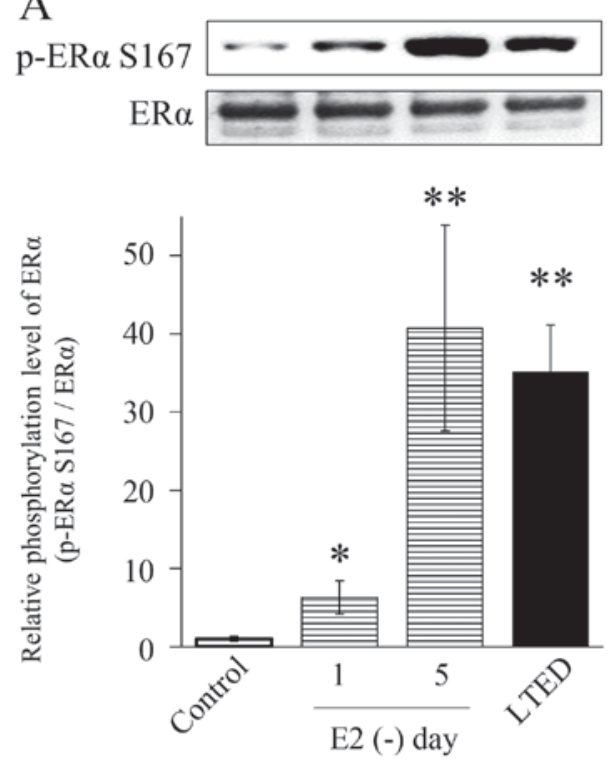

B
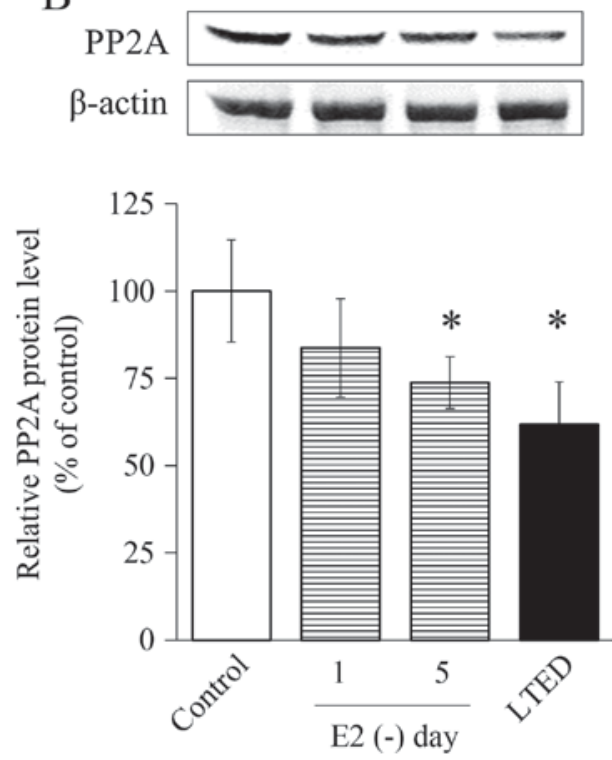

Figure 3. Effect of $\mathrm{E}_{2}$ deprivation on phosphorylated $\mathrm{ER} \alpha$ and PP2A protein levels. (A) MCF-7 cells were cultured without $\mathrm{E}_{2}$ for 0,1 , or 5 days or under LTED. (B) Phosphorylated ER $\alpha$ Ser167 and PP2A protein levels were analyzed by western blotting; ${ }^{*} \mathrm{P}<0.01,{ }^{* *} \mathrm{P}<0.001$. ER $\alpha$, estrogen receptor- $\alpha$; PP2A, protein phosphatase $2 \mathrm{~A} ; \mathrm{E}_{2}$, estradiol; LTED, long-term $\mathrm{E}_{2}$-deprived.

A
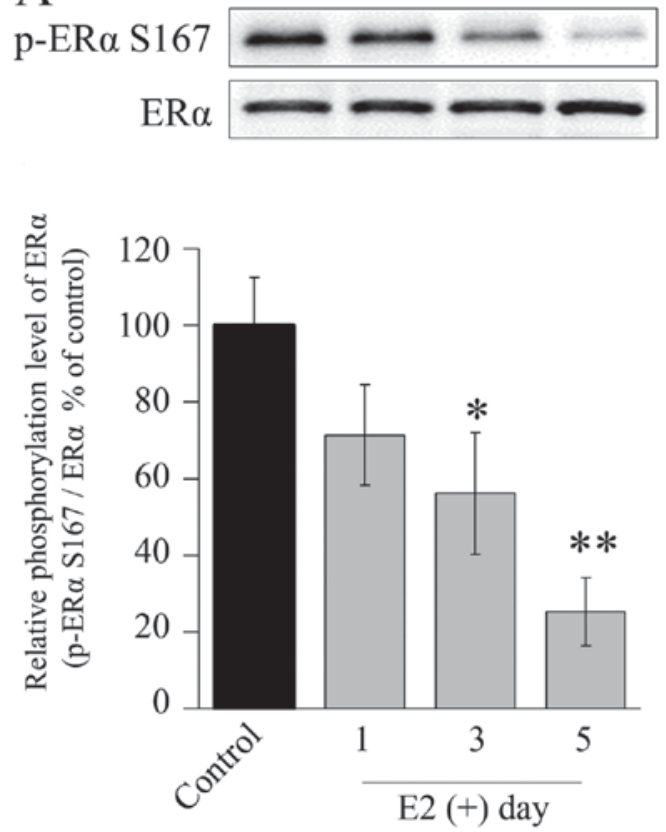

B
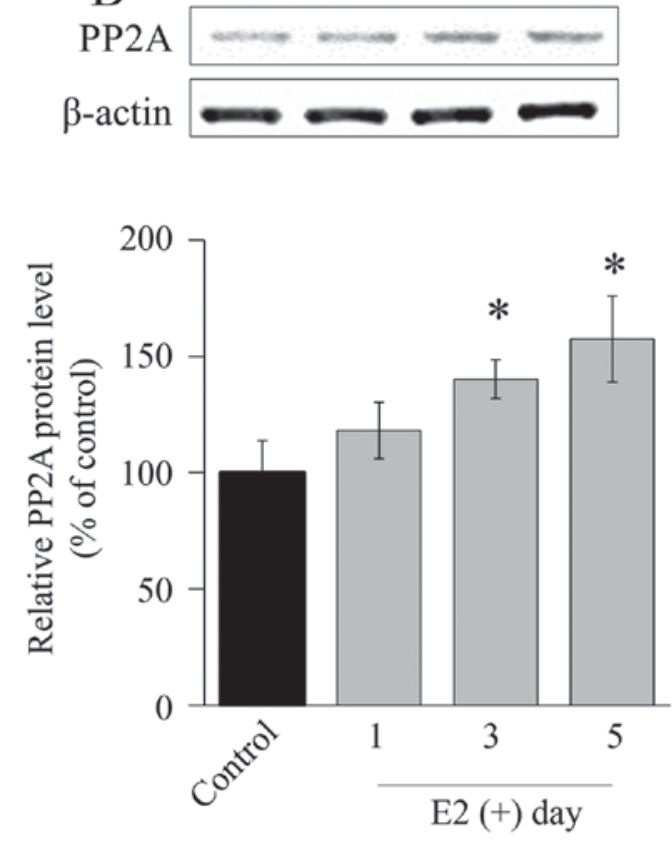

Figure 4. Effect of $\mathrm{E}_{2}$ on the PP2A protein level. LTED cells were cultured with $\mathrm{E}_{2}$ for 0, 1, 3 or 5 days. (A) Phosphorylated ER $\alpha$ Ser167 and (B) PP2A protein levels were analyzed by western blotting; ${ }^{*} \mathrm{P}<0.01,{ }^{* *} \mathrm{P}<0.001 . \mathrm{E}_{2}$, estradiol; PP2A, protein phosphatase $2 \mathrm{~A}$; LTED, long-term $\mathrm{E}_{2}$-deprived; ER $\alpha$, estrogen receptor- $\alpha$.

whereas that in MCF-7 cells cultured under $\mathrm{E}_{2}$ depletion for 5 days with LTED increased by 35 -fold or more, relative to untreated cells (Fig. 3A). By contrast, after 1 day without $\mathrm{E}_{2}$ in the medium, PP2A protein levels decreased to $60 \%$ of the baseline value (Fig. 3B).

PP2A is upregulated by $E_{2}$ under LTED conditions. Phosphorylation of ER $\alpha$ Ser167 in LTED cells was reduced by $E_{2}$ exposure, consistent with the results observed in the parental MCF-7 cells. ER $\alpha$ Ser167 phosphorylation in LTED cells was significantly decreased by exposure to $E_{2}$ in a time-dependent manner (Fig. 4A). However, 3 days after addition of $\mathrm{E}_{2}$ to the medium, PP2A protein levels were significantly increased (Fig. 4B).

PP2A activation enhances the effect of Eve. Following $\mathrm{E}_{2}$ treatment, PP2A expression was increased in the medium. These results indicated that PP2A expression was modulated 


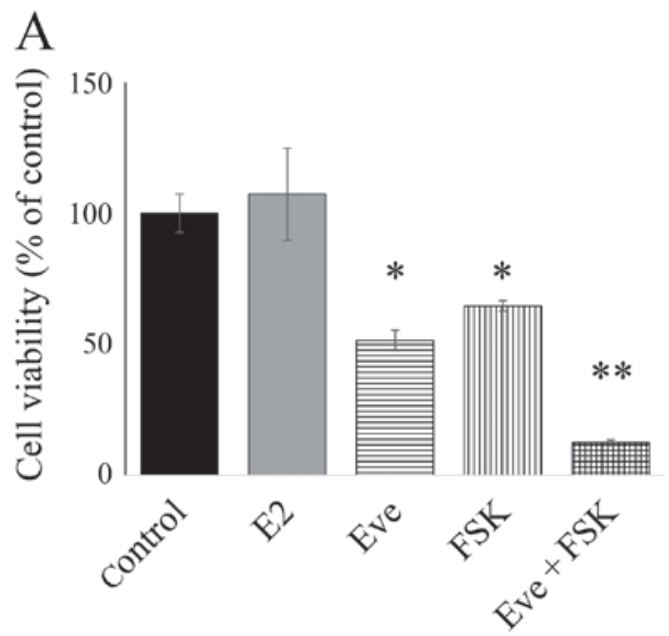

$\mathrm{B}$

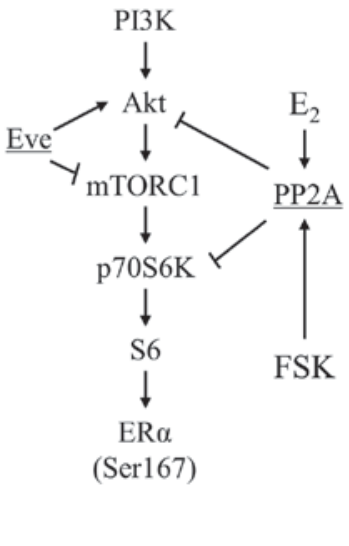

Figure 5. Combination of Eve and FSK reduced the viability of LTED cells. (A) Cell Counting kit-8 assay showing the effect of $\mathrm{E}_{2}(10 \mathrm{nM})$, Eve (10 nM), and FSK $(5 \mu \mathrm{g} / \mathrm{ml})$, alone or in combination, in LTED cells; ${ }^{*} \mathrm{P}<0.01,{ }^{* *} \mathrm{P}<0.001$. (B) Schematic diagram of the signaling pathway in $\mathrm{E}_{2}$-deprived breast cancer cells, showing the effects of Eve, FSK and $\mathrm{E}_{2}$. Eve, everolimus; FSK, forskolin; $\mathrm{E}_{2}$, estradiol; LTED, long-term $\mathrm{E}_{2}$-deprived; PI3K, phosphoinositide 3-kinase; Akt, RAC serine/threonine-protein kinase; mTORC1, mechanistic target of rapamycin complex 1.

by $\mathrm{E}_{2}$ and has a major role in resistance to $\mathrm{E}_{2}$ depletion. Therefore, we hypothesized that PP2A activation increases the effect of Eve. FSK is an activator of PP2A. $\mathrm{E}_{2}$ induced cell growth in ER $\alpha$-positive LTED cells. To investigate the role of PP2A in this process, the potential role of PP2A activation by FSK in cell death was determined. LTED cells in $\mathrm{E}_{2}$-depleted medium were treated with Eve $(10 \mathrm{nM})$ and/or the PP2A activator FSK $(5 \mathrm{mg} / \mathrm{ml})$ for 5 days. FSK and Eve significantly inhibited cell growth. In addition, the combination of Eve and FSK significantly reduced cell growth (Fig. 5A). $\mathrm{E}_{2}$ did not suppress the growth of LTED cells despite increased PP2A expression (Fig. 5A).

\section{Discussion}

Resistance to AIs is an important clinical problem in oncology. In the present study, PP2A was demonstrated to be an important inhibitory factor for signal activation via phosphorylation of ER $\alpha$ Ser167 in breast cancer MCF-7 cells. PP2A activation by FSK increased the appearance of LTED the effect of Eve. On the basis of these results, it was suggested that FSK may serve an auxiliary role in treating AIs-resistant breast cancer.

In a typical cell, the functions of nearly one-third of proteins are regulated via phosphorylation, and this process controls various biological functions, including cell division, growth, proliferation, and apoptosis $(29,30)$. Depending upon the physiological requirements of the cell, proteins transiently shift from a phosphorylated to a dephosphorylated state, with the balance controlled by protein kinases and phosphatases $(30,31)$. PP2A, a serine/threonine protein phosphatase, has been previously suggested to be a tumor suppressor protein in AIs-resistant ER-positive breast cancer cells $(17,28,32)$. In the present study, PP2A tumor suppressor activity was first observed upon treatment with OA, a selective but not specific inhibitor of PP2A, which potently promoted resistance to $\mathrm{E}_{2}$ deprivation in MCF-7 cells. It was subsequently demonstrated that the combination of the
PP2A activator FSK and Eve significantly decreased LTED cell viability. The only known targets of OA are the catalytic subunits PP1 and PP2A, which are essential components of two basic cellular functions: Growth and cell division $(31,33)$. Previously, co-immunoprecipitation and in vitro pull-down assays revealed a direct association between the PP2A-B55 holoenzyme, and Akt; the selectivity of the holoenzyme regulates Akt Thr308 phosphorylation (34).

Our previous study indicated that inhibition of PP2A significantly increases ER $\alpha$ phosphorylation (17). Furthermore, the present study demonstrated that expression of PP2A decreased in response to $\mathrm{E}_{2}$ depletion. As presented in Fig. 1, the responsiveness of Era phosphorylation to rapamycin in MCF-7 and LTED cells after 5 days of $\mathrm{E}_{2}$ depletion was poor. This result indicates that inactivation of $\mathrm{S} 6 \mathrm{~K}$ was slowed by the reduction of PP2A expression (35). Owing to its substantial effect on ER $\alpha$ phosphorylation, the reduction in PP2A levels is considered to contribute to the abnormal activation of IGF-I receptor/insulin receptor substrate-2 or promote AIs-acquired resistance (36). Cancerous inhibitor of PP2A is a novel oncogene that is frequently overexpressed in breast cancer, and has been reported to be downregulated by the phytoestrogen genistein, which has a high affinity for the estrogen receptor (32).

Eve induces Akt activation. PP2A is an important molecule for Akt suppression, however is downregulated in the $\mathrm{E}_{2}$ depleted state. The present study suggested that PP2A activation by FSK is a means to eliminate the effect of the decrease in PP2A levels, and it may be effective to use FSK in addition to the AIs and Eve combination (Fig. 5B). The present study supports the previous implication of PP2A (37) as a therapeutic target in AI-resistant breast cancer.

\section{Acknowledgements}

The present study was supported in part by Grants-in-Aid for Scientific Research from the Ministry of Education, Science, 
Sports, and Culture of Japan (grant no. 25461398), Aichi Cancer Research Foundation (grant no. 673) and Grants-in-Aid for Research from Fujita Health University (grant no. 0).

\section{References}

1. Klinge CM: Estrogen receptor interaction with estrogen response elements. Nucleic Acids Res 29: 2905-2919, 2001.

2. Platet N, Cathiard AM, Gleizes M and Garcia M: Estrogens and their receptors in breast cancer progression: A dual role in cancer proliferation and invasion. Crit Rev Oncol Hematol 51: 55-67, 2004.

3. Lin NU and Winer EP: Advances in adjuvant endocrine therapy for postmenopausal women. J Clin Oncol 26: 798-805, 2008.

4. Cuzick J, Sestak I, Baum M, Buzdar A, Howell A, Dowsett M and Forbes JF; ATAC/LATTE investig: Effect of anastrozole and tamoxifen as adjuvant treatment for early-stage breast cancer: 10-year analysis of the ATAC trial. Lancet Oncol 11: 1135-1141, 2010.

5. BIG 1-98 Collaborative Group, Mouridsen H, Giobbie-Hurder A, Goldhirsch A, Thürlimann B, Paridaens R, Smith I, Mauriac L, Forbes J, Price KN, et al: Letrozole therapy alone or in sequence with tamoxifen in women with breast cancer. N Engl J Med 361: 766-776, 2009

6. Regan MM, Neven P, Giobbie-Hurder A, Goldhirsch A, Ejlertsen B, Mauriac L,Forbes JF, Smith I, Láng I, Wardley A, et al: Assessment of letrozole and tamoxifen alone and in sequence for postmenopausal women with steroid hormone receptor-positive breast cancer: The BIG 1-98 randomised clinical trial at 8.1 years median follow-up. Lancet Oncol 12: 1101-1108, 2011.

7. Becker MA, Ibrahim YH, Cui X, Lee AV and Yee D: The IGF pathway regulates ER $\alpha$ through a S6K1-dependent mechanism in breast cancer cells. Mol Endocrinol 25: 516-528, 2011.

8. Yamnik RL, Digilova A, Davis DC, Brodt ZN, Murphy CJ and Holz MK: S6 kinase 1 regulates estrogen receptor alpha in control of breast cancer cell proliferation. J Biol Chem 284: 6361-6369, 2009.

9. Boulay A, Rudloff J, Ye J, Zumstein-Mecker S, O'Reilly T, Evans DB, Chen S and Lane HA: Dual inhibition of mTOR and estrogen receptor signaling in vitro induces cell death in models of breast cancer. Clin Cancer Res 11: 5319-5328, 2005.

10. Miller TW, Hennessy BT, González-Angulo AM, Fox EM, Mills GB, Chen H, Higham C, García-Echeverría C, Shyr Y and Arteaga CL: Hyperactivation of phosphatidylinositol-3 kinase promotes escape from hormone dependence in estrogen receptor-positive human breast cancer. J Clin Invest 120 2406-2413, 2010.

11. Orti E, Bodwell JE and Munck A: Phosphorylation of steroid hormone receptors. Endocr Rev 13: 105-128, 1992.

12. Fox EM, Kuba MG, Miller TW, Davies BR and Arteaga CL: Autocrine IGF-I/insulin receptor axis compensates for inhibition of AKT in ER-positive breast cancer cells with resistance to estrogen deprivation. Breast Cancer Res 15: R55, 2013.

13. Le Goff P, Montano MM, Schodin DJ and Katzenellenbogen BS: Phosphorylation of the human estrogen receptor. Identification of hormone-regulated sites and examination of their influence on transcriptional activity. J Biol Chem 269: 4458-4466, 1994.

14. Arnold SF, Obourn JD, Jaffe H and Notides AC: Serine 167 is the major estradiol-induced phosphorylation site on the human estrogen receptor. Mol Endocrinol 8: 1208-1214, 1994.

15. Haystead TA, Sim AT, Carling D, Honnor RC, Tsukitani Y, Cohen P and Hardie DG: Effects of the tumour promoter okadaic acid on intracellular protein phosphorylation and metabolism. Nature 337: 78-81, 1989.

16. Suganuma M, Fujiki H, Suguri H, Yoshizawa S, Hirota M, Nakayasu M, Ojika M, Wakamatsu K, Yamada K and Sugimura T: Okadaic acid: An additional non-phorbol-12-tetradecanoate-13-acetate-type tumor promoter. Proc Natl Acad Sci USA 85: 1768-1771, 1988 .

17. Hayashi T, Hikichi M, Utsumi T, Harada N and Yukitake J: Inhibition of PP2A in MCF-7 cells leads to hormone-independent growth. Int J Anal Bio-Sci 4: 1-5, 2016.
18. Mumby M: PP2A: Unveiling a reluctant tumor suppressor. Cell 130: 21-24, 2007.

19. Westermarck J and Hahn WC: Multiple pathways regulated by the tumor suppressor PP2A in transformation. Trends Mol Med 14: 152-160, 2008.

20. Kong M, Fox CJ, Mu J, Solt L, Xu A, Cinalli RM, Birnbaum MJ, Lindsten $\mathrm{T}$ and Thompson CB: The PP2A-associated protein alpha4 is an essential inhibitor of apoptosis. Science 306: 695-698, 2004.

21. Sontag E: Protein phosphatase 2A: The trojan horse of cellular signaling. Cell Signal 13: 7-16, 2001.

22. Janssens V and Goris J: Protein phosphatase 2A: A highly regulated family of serine/threonine phosphatases implicated in cell growth and signalling. Biochem J 353: 417-439, 2001.

23. Eichhorn PJ, Creyghton MP and Bernards R: Protein phosphatase 2 A regulatory subunits and cancer. Biochim Biophys Acta 1795: $1-15,2009$.

24. Shim WS, Conaway M, Masamura S, Yue W, Wang JP, Kmar R and Santen RJ: Estradiol hypersensitivity and mitogen-activated protein kinase expression in long-term estrogen deprived human breast cancer cells in vivo. Endocrinology 141: 396-405, 2000.

25. Santen RJ, Song RX, Zhang Z, Kumar R, Jeng MH, Masamura A, Lawrence J Jr, Berstein L and Yue W: Long-term estradiol deprivation in breast cancer cells up-regulates growth factor signaling and enhances estrogen sensitivity. Endocr Relat Cancer 12 (Suppl 1): S61-S73, 2005.

26. Walter P, Green S, Greene G, Krust A, Bornert JM, Jeltsch JM, Staub A, Jensen E, Scrace G, Waterfield M, et al: Cloning of the human estrogen receptor cDNA. Proc Natl Acad Sci USA 82: 7889-7893, 1985 .

27. Levenson AS and Jordan VC: MCF-7: The first hormone-responsive breast cancer cell line. Cancer Res 57: 3071-3078, 1997.

28. Baldacchino S, Saliba C, Petroni V, Fenech AG, Borg N and Grech G: Deregulation of the phosphatase, PP2A is a common event in breast cancer, predicting sensitivity to FTY720. EPMA J 5: 3, 2014

29. Duronio RJ and Xiong Y: Signaling pathways that control cell proliferation. Cold Spring Harb Perspect Biol 5: a008904, 2013.

30. Bononi A, Agnoletto C, De Marchi E, Marchi S, Patergnani S, Bonora M, Giorgi C, Missiroli S, Poletti F, Rimessi A and Pinton P: Protein kinases and phosphatases in the control of cell fate. Enzyme Res 2011: 329098, 2011.

31. Mumby MC and Walter G: Protein serine/threonine phosphatases: Structure, regulation, and functions in cell growth. Physiol Rev 73: 673-699, 1993.

32. Zhao Q, Zhao M, Parris AB, Xing Y and Yang X: Genistein targets the cancerous inhibitor of PP2A to induce growth inhibition and apoptosis in breast cancer cells. Int J Oncol 49: 1203-1210, 2016

33. Holmes CF, Luu HA, Carrier F and Schmitz FJ: Inhibition of protein phosphatases-1 and -2A with acanthifolicin. Comparison with diarrhetic shellfish toxins and identification of a region on okadaic acid important for phosphatase inhibition. FEBS Lett 270: 216-218, 1990

34. Kuo YC, Huang KY, Yang CH, Yang YS, Lee WY and Chiang CW: Regulation of phosphorylation of Thr-308 of Akt, cell proliferation, and survival by the B55alpha regulatory subunit targeting of the protein phosphatase $2 \mathrm{~A}$ holoenzyme to Akt. J Biol Chem 283: 1882-1892, 2008

35. Peterson RT, Desai BN, Hardwick JS and Schreiber SL: Protein phosphatase $2 \mathrm{~A}$ interacts with the $70-\mathrm{kDa}$ S6 kinase and is activated by inhibition of FKBP12-rapamycinassociated protein. Proc Natl Acad Sci USA 96: 4438-4442, 1999.

36. Hurvitz SA and Pietras RJ: Rational management of endocrine resistance in breast cancer: A comprehensive review of estrogen receptor biology, treatment options, and future directions. Cancer 113: 2385-2397, 2008.

37. Li L, Zhang J, Xiong N, Li S, Chen Y, Yang H, Wu C, Zeng H and Liu Y: Notch-1 signaling activates NF- $\kappa \mathrm{B}$ in human breast carcinoma MDA-MB-231 cells via PP2A-dependent AKT pathway. Med Oncol 33: 33, 2016. 